\title{
クリーニング作用域に形成されるアルミニウム合金の 微細割れの検討*
}

\author{
加藤 光昭**, 西尾 一政**, 山口 富子**, 迎 静雄**
}

Microcracks of Aluminum Alloys Developed in Cleaning Action Region*

by Mitsuaki Katoh**, Kazumasa Nishio**, Tomiko Yamaguchi** and Shizuo Mukae**

Microcracks developed in cleaning action region by GTA process have been investigated using an aluminum and aluminum alloys. Although no microcracks are observed in a pure aluminum and a commercially pure aluminum, microcracks are mainly developed in the region of $\mathrm{Al}-\mathrm{Mg}$ alloys where the oxide film is broken due to the cleaning action. This tendency of cracks is quite the same as the weld solidification crack. The microcracks are easily developed with the increase in EN ratio of the welding current. Since dendrites are observed on the crack surface, the microcracks is intergranular due to the solidification crack. The cooling rate in this case was estimated to be about $10^{40} \mathrm{C}$ using the size of the dendrites. The microcracks are considered to be developed due to the phenomena that the region where the oxide film is broken is locally melted owing to the high current density and the cooling rate is very high. $\mathrm{X}$-ray diffraction technique made clear that the continuous vague Debye-Scherrer rings are obtained from the region where the oxide film is broken even when using a single crystal. This shows that the single crystal changes to very small polycrystals in this region and the polycrystallized depth from the specimen surface was about $100 \mu \mathrm{m}$. Fatigue strength at $1 \times 10^{7}$ cycles of specimens having the microcracks is lower than that of the base metal and decreases linearly with the increase in the crack depth.

Key Words: Microcracks, Aluminum Alloy, Cleaning Action, Solidification Crack, EN Ratio, Cooling Rate, Oxide Film, Single Crystal, Debye-Scherrer Ring, Fatigue Strength

\section{1. 緒言}

アルミニウム合金 6061 を交流を用いてティグ溶接す ると，熱影響部の表面に微細な割れが発生することが報 告されている1.この割れは，予熱あるいはパス間温度に 起因して母材の温度が高く，アーク長が長く，それに高 周波を重畳させて溶接した場合に発生しやすいと報告さ れている. またミグ溶接したアルミニウム合金 2014T6の熱影響部にも微細な割れが認められ，これはミグ 溶接の表層部の粒界の融解，スパッ夕あるいは局所的な アークプラズマの衝突に起因していると報告されてい る2. 更に，田中らはA5083 及び A6061 などの押出材を 交流ティグ溶接した際に,クリーニング作用域に微細な 割れが発生することがあると報告している ${ }^{3)}$ 。この割れ は，電流の正極性成分を增大させたりあるいはアルゴン ガス流量を減らしてクリーニング作用域を減少させるこ とにより，減少あるいはなくすことができるとされてい

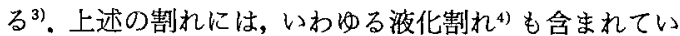
ると考えられるが，このような微細な割れは，溶接継手 の性能汇も影響を及沽すと考元られる。

本研究では, クリーニング作用域に形成される微細割 れに注目し，材質及び電流の正極性成分の影響について 検討した，次に，単結晶材を用いたときの割れの形成に ついて検討した. 更に，微細割れを有する試験材の疲学 特性についても検討した。

*原稿受付 平成 5 年11月 4 日 平成 5 年度秋季全国大会で発表

**正 員 九州工業大学 Member, Kyushu Institute of Technology

\section{2. 使用材料及び実験方法}

本研究て使用した材料は, A1050, Al- $1 \% \mathrm{Mg}$ 合金, $\mathrm{Al}$ $-2 \% \mathrm{Mg}$ 合金， $\mathrm{A} 1-3 \% \mathrm{Mg}$ 合金，及びアルミニウム合金 A5052 とA5083 である。試験片の寸法は, 板厚 $2 \mathrm{~mm}$,

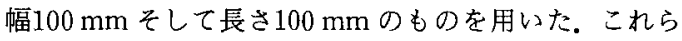

Table 1 Chemical compositions of materials used (mass\%).

\begin{tabular}{|c|c|c|c|c|c|c|c|c|c|}
\hline Materials & si & $\mathrm{Fe}$ & $\mathrm{Cu}$ & $M_{n}$ & $\mathrm{Mg}$ & $z_{n}$ & $\mathrm{Gr}$ & $\mathrm{Ti}$ & $A 1$ \\
\hline A1050 & 0.25 & 0.10 & 0.05 & 0.05 & 0.05 & 0.05 & - & 0.03 & Bal. \\
\hline A1-1XWB $A \perp$ loy & 0.04 & 0.07 & - & - & 0.86 & - & - & - & Bal. \\
\hline$A 1-2 x M_{g}$ Alloy & 0.01 & 0.01 & - & - & 1.81 & - & - & - & Bal. \\
\hline$A 1-3 X X_{B}$ Alloy & 0.01 & 0.01 & - & - & 2.98 & - & - & - & Bal. \\
\hline Asos 2 & 0.25 & 0.10 & 0.10 & 0.10 & 2.50 & 0.10 & 0.20 & - & Bal. \\
\hline A5083 & 0.09 & 0.26 & 0.01 & 0.63 & 1.20 & 0.01 & 0.17 & 0.10 & Bal. \\
\hline
\end{tabular}

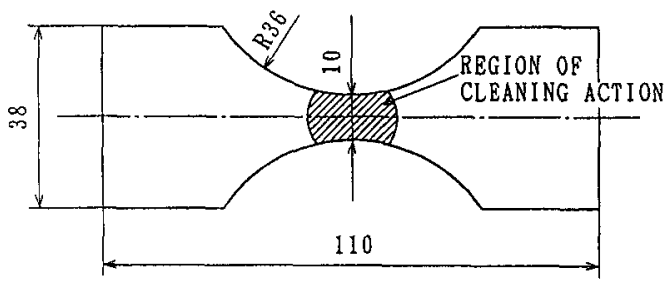

Fig. 1 Shape and dimensions of a specimen for fatigue test. 
の材料は微細割れに及ほす材質の影響を検討するために 用いたが，A1050を除いた他の合金においては微細割れ が認められたため, その他の検討は A5083を用いて行っ た. 単結晶材に対して検討する際には, A5083に0.8\%の 引張塑性ひずみを与えたのち $600^{\circ} \mathrm{C} て ゙ 15 \mathrm{~h}$ 焼きなましを することにより大きさが約 $20 \mathrm{~mm}$ の粗大結晶が得られ たため,このうちの任意の結晶を用いた。それそれれの材 料の化学組成は Table 1 に示すとおりである.

溶接機は交直両用ティグアーク溶接機(侏ダイヘン製, エレクトロコンパ300S) を用い，トーチは固定して使用 した。電極はトリウム入りタングステン棒 $(\phi 4)$ を用い, 先端は約 $90^{\circ}$ にグラインダで加工した. 電極の先端と試 験片表面の距離を $l=3,4,5$ そして $6 \mathrm{~mm}$ と変化させ た. 電流の正極性成分 (以下, EN (Electrode Negative) 比という) は $\beta=50,60$ そして $70 \%$ と変化させた ( $\mathrm{EN}$ 比 が増大すると共にクリーニング作用は減少する). また, 溶接電流は安定なアークが出ずにクリーニング作用のみ が起こるように, I= 30 A とした(一部, I= 50 A でスポ ット溶接も行った). 更に, 通電時間は $\mathrm{t}=20 \mathrm{~s}$ とした.

微細割れの形成の程度は, クリーニング作用域を倍率 10倍のプロジェクターを用いて観察し, 割れの観察され る面積及びクリーニング作用域に占める面積率で評価し た.クリーニング作用域及び割れの認められた領域の面 積は，それぞれの領域を円で近似して求めた。

疲労試験は平面曲げ疲労試験機 (島津製作所(侏製, UF -15）を用い, 両振り試験を行った. 疲労試験片の形状・ 寸法を Fig. 1 に示す. 図中の斜線を施した領域の面積は クリーニング作用域である。

\section{3. 実験結果及びその考察}

\section{1 割れの形成に及ぼす材質及び EN 比の影響}

Fig. 2 (a)，(b)及び(c)にそれぞれA1050，A5052 及び
$\mathrm{A} 5083$ のクリーニング作用域のマクロ組織を示す（ $l=5$ $\mathrm{mm}, \beta=60 \%)$. 白く円形状に認められるのがクリーニン グ作用域である.また, 中央部付近に粒状に認められる
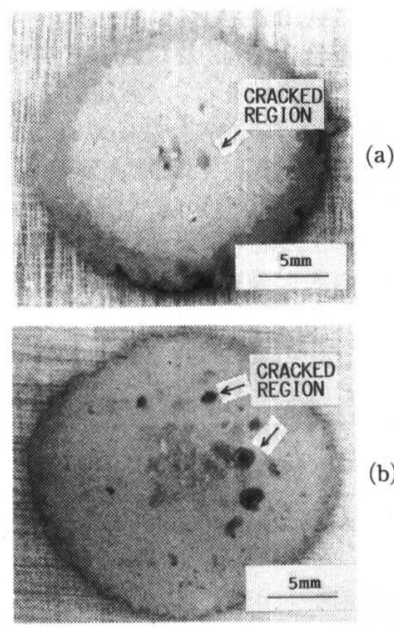

(b)

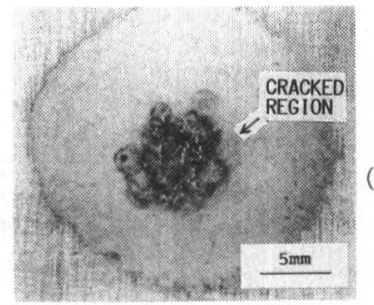

Fig. 2 Macrostructures of regions of cleaning action ( $l=5 \mathrm{~mm}, \beta=60 \%$ ). (a) A1050, (b) A5052, (c) A5083. (a) (a)

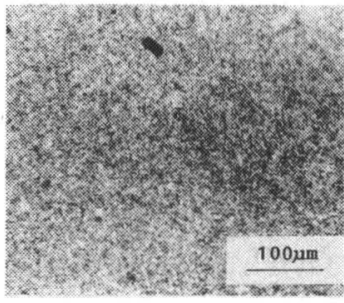

(c)

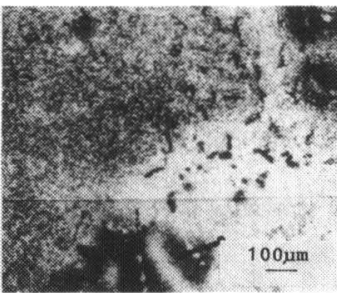

(e)

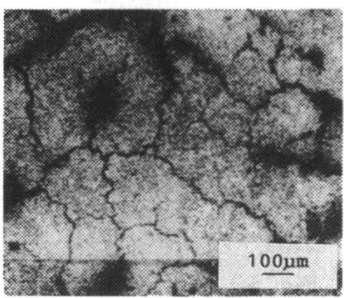

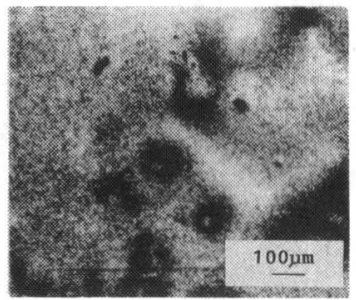

(b)

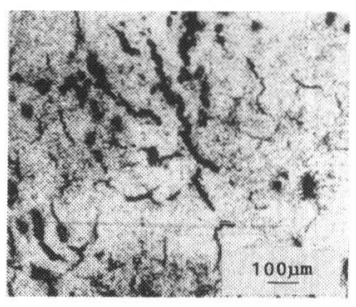

(d)

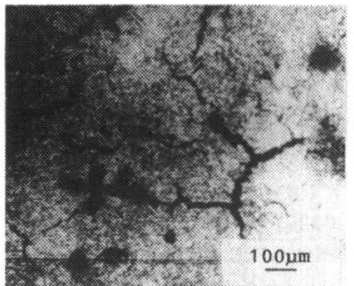


のは酸化皮膜の破れた領域である.A1050においては数 個所しか酸化皮膜は破れていないが，A5052 には酸化皮 膜が破れた領域が点在して認められ, A5083においては 中央部付近に集中して認められる.

Fig. 3 (a) (f) に A1050, Al-1\% Mg 合金, Al-2\% Mg 合 金, $\mathrm{Al}-3 \% \mathrm{Mg}$ 合金, $\mathrm{A} 5052$ 及び A5083 の酸化皮膜が破 られた領域のミクロ組織を示す. A1050 においては割れ は認められないが, その他の合金においてはいずれも微 細な割れが認められる。予備実験の結果によると, $99.99 \% \mathrm{Al}$ 及び A1100においても割れは認められてい ない.また, Fig. 3 の結果によれば $\mathrm{Al}-3 \% \mathrm{Mg}$ 合金及び A5052 において多数の微細割れが認められる.この傾向 は, $\mathrm{Al}-\mathrm{Mg}$ 系合金の溶接凝固割れ感受性と類似してお り,クリーニング作用域に形成される微細割れは凝固割

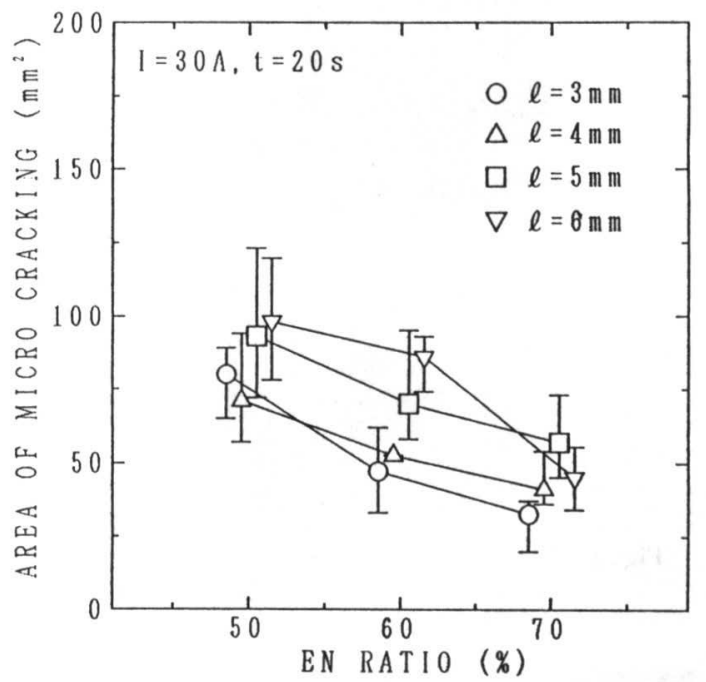

(a)

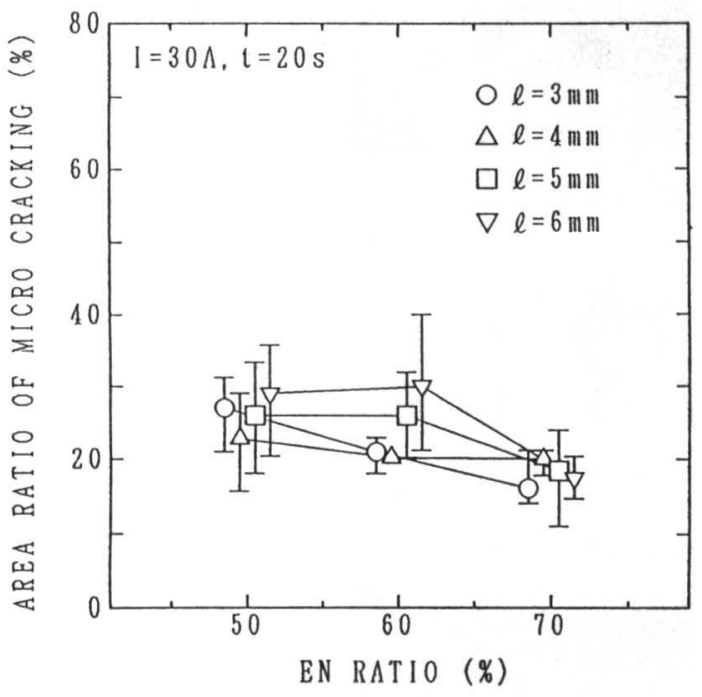

(b)

Fig. 4 Influence of EN ratio on microcracking. (a) Relation between area of microcrack ing and EN ratio, (b) Relation between area ratio of microcracking and $\mathrm{EN}$ ratio.
れに関係していることが予想される。また，微細割れは 酸化皮膜が破られた領域に多く認められた。

Fig. 4 (a)及び(b)にそれぞれ A5083 のクリーニング作 用域において微細割れの認められた領域の面積と EN 比の関係及び微細割れの認められた領域の面積率と EN 比の関係を示す. Fig. 4(a)においては, EN 比が70, 60そ して $50 \%$ と減少すると共に微細割れの領域の面積は增大 する傾向が認められる.これは, EN 比の減少と共にクリ ーニング作用の生じる領域が増大することに対応してお り, ここで認められる微細割れはクリーニング作用に起 因するものであると考えてよい.また，電極の先端と試 験片表面間の距離 $l$ を変化させたところ, ばらつきが認 められるが, $l$ の增大と共に面積は増大する傾向がある. これは $l$ の増大に伴いクリーニング作用の生じる領域が 増大することに起因している（例えば， I= $30 \mathrm{~A}, \mathrm{EN}$ 比 が $60 \%$ の場合, $l$ が, $3,4,5$ 及び $6 \mathrm{~mm}$ と增大すると, クリーニング作用域の面積は $223,260,269$ 及び $287 \mathrm{~mm}^{2}$ と増大した). Fig. 4 (b)に示した微細割れの面積率と EN 比の関係においては, EN 比の減少に伴う面積率の増大 はFig. 4 (a)の変化と比べると小さいが，クリーニング作 用の生じる領域が最も小さい $\beta=70 \%$ の場合が割れ率は 最も小さい.

\section{2 単結晶材に対する検討}

Fig. 5 亿単結晶材にクリーニング作用を生じさせた領 域 $(l=5 \mathrm{~mm}, \beta=60 \%)$ のマクロ組織を示す. 中央部付 近に粒状に認められるのは酸化皮膜が破られた領域であ る. Fig. 6 (a)及び(b)に Fig. 5 の酸化皮膜が破られた領域 及び割れ断面のSEM 写真を示す. Fig. 6(a)においては 微細割れが多数認められる. Fig. 6(b)から明らかなよう に, 割れは試験片表面にほほ垂直に認められ, この深さ は約 $100 \mu \mathrm{m}$ である。

クリーニング作用域を含む試験片を引張試験すること により得た割れ破面の SEM 写真を Fig. 7 に示す. Fig. 7 (a)は割れの深さ方向のほほ全景であり， $5 \sim 6 \mu \mathrm{m}$ の太 さの柱状の組織(これは試験片表面にまでほほ同じ大き さで認められ，それぞれがひとつの結晶に対応すると考 えれる.) が多数認められる. Fig. 7 (b)は割れ破面を拡大 したものであり, デンドライトが凝固した様子がはっき りと認められることから,この微細割れは陰極点が形成 されたところが局所的に融解したことにより発生したと 考えられる。また，これは粒界割れである。ところで, デンドライトの大きさを用いると, 凝固時の冷却速度を 推定することができる. T.F. Bower らは, Al-Cu 合金に 対して検討し, デンドライトの間隔 $\mathrm{d}(\mu \mathrm{m})$ と冷却速度 $\mathrm{C}_{\mathrm{R}}$ の間に式(1)の関係が成り立つことを報告している5.

$$
\mathrm{d}=70 \mathrm{C}_{\mathrm{R}}^{-0.39}
$$

本研究で使用した材料は $\mathrm{Al}-\mathrm{Mg}$ 合金 A5083であり,

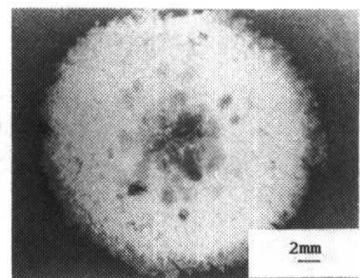

Fig. 5 Macrostructure of region of cleaning action for a single crystal $(l=5 \mathrm{~mm}, \beta=$ $60 \%)$. 


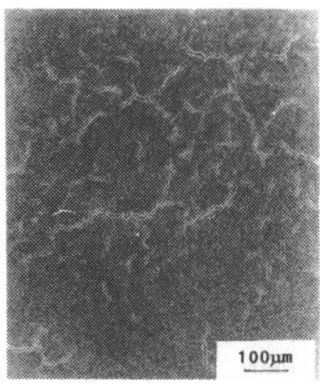

(a)

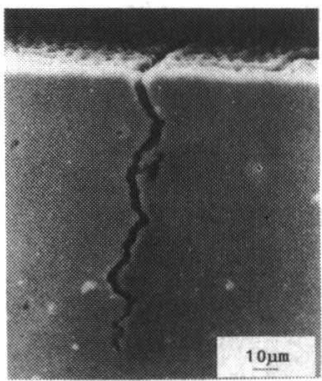

(b)

Fig. 6 SEM photographs of regions of cleaning action for a single crystal $(l=5 \mathrm{~mm}, \beta=$ $60 \%$ ). (a) Region in which oxide film is broken, (b) Cross section of a microcrack.
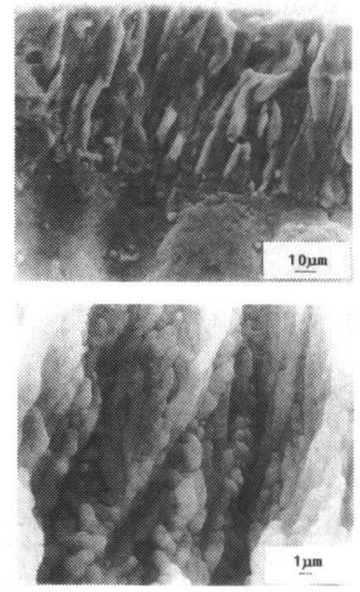

(b)

Fig. 7 SEM fractographs of a microcrack. (a) Overall view of a microcrack, (b) Enlargement of (a).

式(1)を得るのに用いられた材料と異なるが，おおよその 冷却速度を推定するために式(1)を適用する. Fig. 7 (b)に 認められるデンドライトの大きさは $\mathrm{d}=$ 約 $1 \mu \mathrm{m}$ である ため, これを式(1)に代入して冷却速度 $\mathrm{C}_{\mathrm{R}}$ を計算すると, $\mathrm{C}_{\mathrm{R}}=$ 約 $5 \times 10^{40} \mathrm{C} / \mathrm{s}$ となる.この冷却速度は非常に速い が, 陰極点の形成に際しては電流密度が非常に大きくな ることを考えると不合理な值ではない.

ここでは, 単結晶材にクリーニング作用を生じさせた. ところで，A5083のように溶質原子を多量に含んでいる 単結晶材を溶融溶接した場合には, Fig. 8 に示すミクロ 組織からも明かなように, 単結晶は多結晶に変化する(こ の際, 溶接電流は $\mathrm{I}=50 \mathrm{~A}$ とした). しかし,この溶融凝

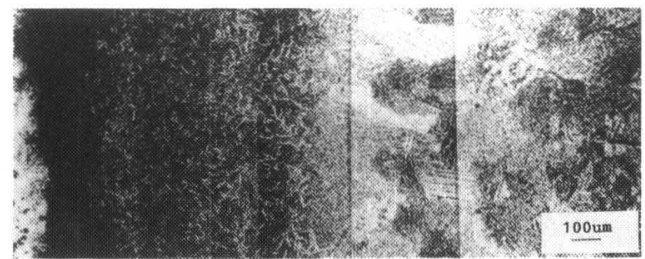

Fig. 8 Microstructure of weld metal of a single crystal.

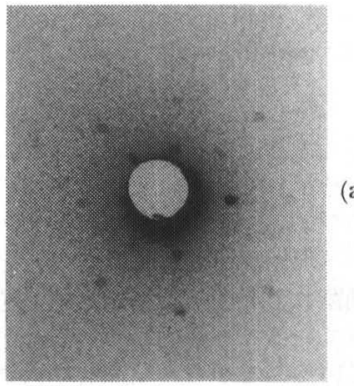

(a)

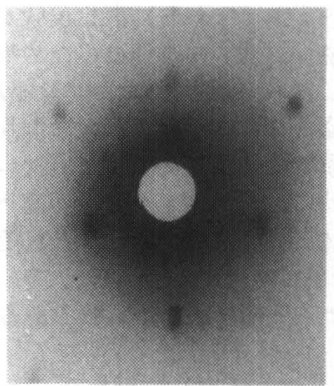

(b)

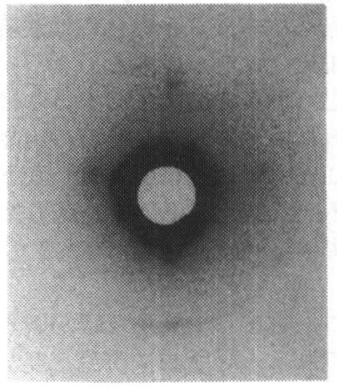

Fig. 9 Laue photographs obtained from some regions of a specimen shown in Fig. 5. (a) Base metal, (b) Region of cleaning action in which oxide film is not broken, (c) Region of cleaning action in which oxide film is broken.

固した領域にはいわゆるクレータ割れに相当する以外の 割れは認められない.

次に, X線回折法を用いて検討した. Fig. 5 の母材, 酸 化皮膜が破られていないクリーニング作用域及び酸化皮 膜が破られた領域に X線（ターゲット：Cu，スリット 径： $\phi 1 \mathrm{~mm}$ ) を照射して得られたラウエ写真をそれぞれ Fig. 9 (a), (b)及び(c)に示す. Fig. 9(a)のラウ工斑点はきれ いな棈円形をしており，母材は十分焼きなましされたひ ずみのほとんどない状態であると考えてよい. Fig. 9 (b) のラウエ斑点は少しいびつになり大きさも Fig.9(a)の 


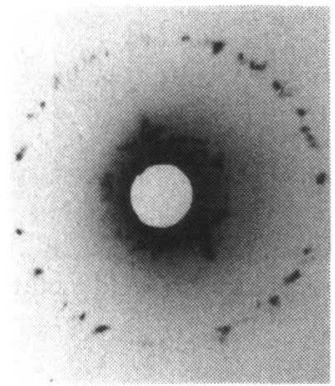

Fig. 10 Debye photograph obtained from a weld metal shown in Fig. 8.

ものと比較すると大きくなっている．これは，ひずみを 受けていることを示している. ラウエ斑点の形状から判 断すると数\%のひずみと考えられる.一方, Fig. 9 (c)に おいては, デバイ環が認められる。このことは, 酸化皮 膜が破られ微細割れの発生した領域は結晶粒の小さい多 結晶で構成されていることを示している.デバイ環はほ とんど連続していることから, 結晶粒の大きさはかなり 小さいと予想される．すなわち，酸化皮膜が破られた領 域は局所的に溶融し, 速い冷却速度のため単結晶も微細 な多結晶に変化したものと考えられる*1. また, うっすら とラウエ斑点も認められるが，これは試験片表面から少 し内部に入った領域は多結晶になっていないことを示し ている (Fig. 9(c)には二つのデバイ環が認められ, 内側 が(511)そして外側が(422)面である。 それぞれのX線の 侵入深さは111及び105 $\mu \mathrm{m}$ であるため, 多結晶に変化し ているのは表面から約 $100 \mu \mathrm{m}$ の領域であると考えられ る).

Fig. 10 にはFig. 8 に示した溶融凝固した領域から得 られたデバイ写真を示す.この場合には連続したデバイ 環は得られず, 斑点状になっている。デバイ斑点の大き さはX線を照射した領域の結晶粒の大きさに対応してい ることから，これは溶融凝固した領域の結晶粒の大きさ が比較的大きいことを示している.これは, Fig. 8 からも 明らかである. Fig. 10 と Fig. 9 (c)を比較しても微細割れ の発生した領域の結晶粒の大きさが小さいことがわか る.

以上のことから，主として酸化皮膜が破られた領域に 認められる微細割れは, 局所的に電流密度が非常に高く なることによりその個所が融解し, $10^{40} \mathrm{C} / \mathrm{s}$ 程度に達す る速い冷却速度で冷却されることにより発生するものと 考えられる。

\section{3 微細割れを有するときの疲労特性}

材料の疲労特性は微細割れが存在する場合にも大きな

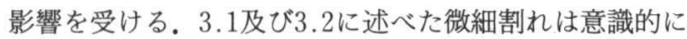
クリーニング作用域を形成し，酸化皮膜が破られた領域 に認められたものであり，アルミニウム合金のティグ溶 接を行ったときに一般的に形成されるものではないが, 疲労特性に及ぽす微細割れの影響を検討するのに適した ものであるため,この微細割れを有する試験材を用いて, 次に疲労試験を行った. 得られた S-N 曲線を Fig. 11 に

*1ここでは単結晶を用いているため, 溶融部が凝固する際にはいわ ゆるエピタキシャル成長をするが，材料が A 5083 であること及び冷 却速度が速いために, エピタキシャル成長する領域は狭く, その後 は新たな核生成により多結晶化したと考えられる。

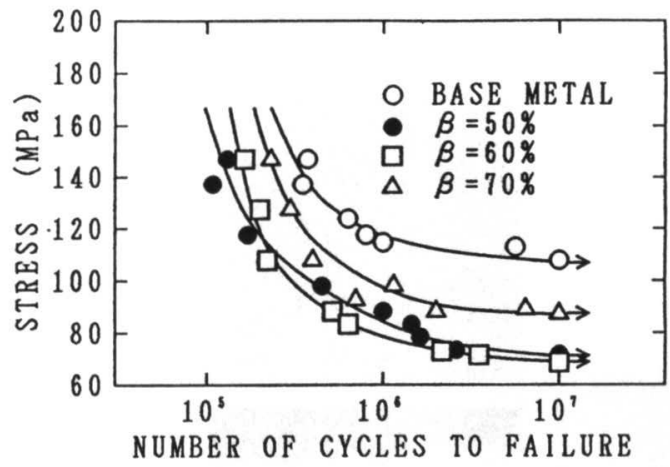

Fig. $11^{\circ} \mathrm{S}-\mathrm{N}$ curves of a base metal and specimens having microcracks.

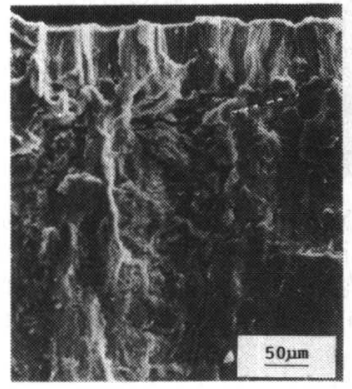

Fig. 12 An example of fractographs after fatigue test.

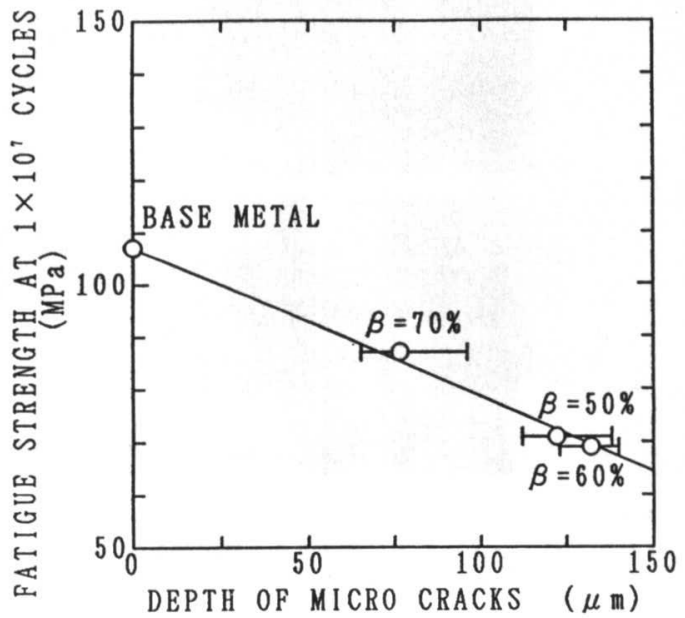

Fig. 13 Relation between fatigue strength at $1 \times 10^{7}$ cycles and depth of microcracks.

示す. Fig. 11 には微紐割れを有しない母材, ならびに $\mathrm{EN}$ 比を $\beta=50,60$ 及び $70 \%$ と変化させたときのものに ついて検討した. 繰返数 $\mathrm{N}=1 \times 10^{7}$ 回における時間強度 は母材が107 MPa と最も大きい.ここで検討したなかで クリーニング作用域の最も小さい $\beta=70 \%$ にいても時 間強度は $87 \mathrm{MPa}$ に減少している.また, $\beta=60$ 及び $50 \%$ の場合には大きな差異は認められないが, 69及び71 MPa の時間強度を有している。

Fig. 11 に示した時間強度の変化は微細割れの深さと 
関係していると予想される。すでに Fig. 4 に示したよう に，微練割れの認められる面積率は EN 比が減少すると 共に増大した，微細割れの梁さは, Fig. 11 に示した S-N 曲線を得た際に破断した試験片を用いて，SEMにより 測定した。疲労破面の例を Fig. 12 に示す.上部に認めら れるのが微細割れであり，これと疲労割れとは明瞭に区 分できる. $\beta=70,60$ 及び $50 \%$ の場合の平均の樑さは $\mathrm{D}=$ 77,132 及び122 $\mu \mathrm{m}$ であった. $\mathrm{N}=1 \times 10^{7}$ 回における時 間強度とこのようにして得られた微細割れの深さの関係 をFig. 13 に示す。假細割れの深さにはばらつきが諗め られたため，その範囲も図中に示した．Fig.13から明ら かなように, 微細割れの深さの増大と洪に時間強度は直 線的に減少し Fig. 11 に示した時間強度の変化は微細割 れの深さと密接な関係があることが明らかになった。

\section{4. 結 論}

(1) 純アルミニウム及び工業用純アルミニウムにおい てはクリーニング作用域に微細割れは認められないが, $\mathrm{Al}-\mathrm{Mg}$ 合金においては主に酸化皮膜が破られた領域に 微細割れが形成される.

(2) 微紐割れは，EN 比が減少すると共に形成されや すくなる。

（3）割れ破面にはデンドライトが認められることか ら，これは凝固割れに起因しており，粒界割れである。 デンドライトの大きさから冷却速度を推定すると $10^{4 \circ} \mathrm{C} /$ sに達した。

(4)これは，酸化皮膜が破られた領域が局所的に電流 密度が非常に大きくなり，そこが融解し，冷却速度が速 いために生じるものと考えられる。

(5) X線回折法を用いて検討した結果，単結晶材に扔 いて微細割れの認められた領域からは連続したデバイ環 が得られ，この領域は小さい多結晶加構成されている ことが明らかになった。

（6）微細割れを有する試験材の綝返数 $1 \times 10^{7}$ 回にお ける時間強度は母材より低下し，時間強度は割れの樑さ が増大すると共に直線的に減少する。

\section{参考 文 献}

1) R.E. Fish, C.S. Shira : Effects of High-Frequency Current in Welding Aluminum Alloy 6061: Weld. J., 45-11 (1966), 490s $-496 \mathrm{~s}$.

2) R.G. Hocker, K.R.Wilson: Dye Penetrant Indications Caused by Superficial Surface Defects in 2014 Aluminum Alloy Welds, Weld. J., 50-11 (1971), 485s-490s.

3）田中一雄, 古金和郎, 米田陽一郎, 要善恒：アルミニウム溶接ビ 一ド際の母材表面割れ汇関する研究，溶接学会全国大会講演概 要, 第41集, (1987), 304-305.

4）溶接学会編：溶接・接合工学の基礎，丸善（1993），161.

5) T.F. Bower, H.D. Brody, M.C. Flemings: Measurements of Solute Redistribution in Dendritic Solidification, Trans. of Metallurgical Society of AIME, 236-5 (1966), 624-634. 